\title{
The importance of protecting surgical instrument tables from intraoperative contamination in clean surgeries ${ }^{1}$
}

\author{
Aline Mesquita Amaral ${ }^{2}$ \\ Augusto Diogo Filho ${ }^{3}$ \\ Mileide Maria de Assunção Sousa ${ }^{4}$ \\ Patrícia Araújo Barbosa ${ }^{5}$ \\ Paulo Pinto Gontijo Filho ${ }^{6}$
}

Objective: to compare the degree of bacterial contamination of surgical instrument tables used in clean surgical procedures, either protected with plastic fields, sterilized with ethylene oxide, or disinfected with $70 \%$ alcohol and $1 \%$ iodine solutions. This is a randomized clinical trial in which samples were collected from the surfaces of surgical instrument tables before and after each procedure. Microbiological analysis was performed to identify microorganisms and their respective antimicrobial resistance. Results: Bacterial growth in the surgeries using sterilized plastic was $5.71 \%$ before and $28.6 \%$ after surgery and, $2.9 \%$ and $45.7 \%$ respectively in surgeries using disinfection with $70 \%$ alcohol and $1 \%$ iodine solutions; no statistical difference was found between the methods. Conclusion: both methods present similar protection, however, $70 \%$ alcohol and $1 \%$ iodine do not generate solid waste.

Descriptors: Hospital Infection; Environmental Contamination; Disinfection; Alcohols; Iodine; Plastics.

\footnotetext{
${ }^{1}$ Paper extracted from Master's Thesis "Experimento randomizado de duas formas de proteção das mesas de instrumentais cirúrgicos em cirurgias limpas" presented to Universidade Federal de Uberlândia, Uberlândia, MG, Brazil. Supported by Coordenação de Aperfeiçoamento de Pessoal de Nível Superior (CAPES).

2 Master's student, Faculdade de Medicina, Universidade Federal de Uberlândia, Uberlândia, MG, Brazil.

${ }^{3}$ PhD, Associate Professor, Surgery Department, Faculdade de Medicina, Universidade Federal de Uberlândia, Uberlândia, MG, Brazil.

${ }^{4}$ Undergraduate student in Medicine, Universidade Federal de Uberlândia, Uberlândia, MG, Brazil. Scholarship holder PIBIC/FAPEMIG.

${ }^{5}$ Undergraduate student in Medicine, Universidade Federal de Uberlândia, Uberlândia, MG, Brazil.

${ }^{6}$ PhD, Full Professor, Microbiology Department, Universidade Federal de Uberlândia, Uberlândia, MG, Brazil.
} 


\section{Introduction}

The control of perioperative contamination has been a mandatory measure to prevent surgical site infection $(\mathrm{SSI})^{(1)}$. Such control consists of preventive measures usually adopted in critical units, such as: cleaning floors, walls and equipment; controlling the access and traffic of people, movement of doors; controlling the ventilation system with positive pressure; and the use of appropriate attire by the surgical team ${ }^{(2)}$.

SSIs are infections that occur in surgical incisions, affecting tissues, organs and cavities manipulated during surgery and may be diagnosed up to 30 days after a procedure. In most hospitals, SSIs are the first or second most frequent sites of infection, sometimes surpassed only by urinary tract infections(3).

Another factor that directly affects SSI rates is the surgery's potential for contamination, that is, the surgery's degree of microbial contamination ${ }^{(4)}$ described as: (1) clean surgeries - those with no infection or inflammatory process in the surgical site and no opening of the respiratory, digestive, or genitourinary tracts; (2) clean-contaminated surgeries - surgeries in which the respiratory, digestive, or genitourinary tracts are opened under controlled conditions, without gross spillage; (3) contaminated surgeries: include open traumatic wounds, less than six hours old, and surgeries with breaches of aseptic technique; and (4) dirty surgeries: include late (more than six hours old) open traumatic wounds, with devitalized tissue and preexisting clinical infection, or with perforation of hollow viscera.

There are, however, various factors that can contribute to SSI pathogenesis. Among them are those related to microorganisms such as virulence and microbial load, and the presence of diseases such as obesity, hypertension, immunosuppression, diabetes mellitus, the use of corticoids, and extreme age groups. In regard to the preoperative and intraoperative periods, the factors include: prolonged preoperative wait, surgical technique, tissue oxygenation, hemodynamic conditions, duration of procedure, length of hospitalization, shaving before surgery, the presence of devitalized tissue, and whether antimicrobial agents were used prior to the surgery ${ }^{(3)}$.

Another factor to consider in relation to SSI is that studies report that antimicrobial prophylaxis is more efficient when it is initiated in the preoperative period and maintained during the intraoperative period, seeking to keep therapeutic blood levels during the entire procedure. Antimicrobial agents should be administered intravenously in most procedures, from 30 minutes to one hour, in induction of anesthesia before surgery. A single dose is the standard prophylaxis, though it depends on the antimicrobial agent used and the duration of the surgical procedure ${ }^{(5)}$.

Due to the influence of specialized literature, the use of sterilized plastic fields, placed under tissue fields on surgical instrument tables, has been, for many years, a standard procedure used in various surgeries performed in general hospitals and hospitals of high complexity.

A previous study addressing this subject, though unpublished, reports no statistical difference between the two methods: disinfection with $70 \%$ alcohol and $1 \%$ iodine and sterilized plastic fields ${ }^{(6)}$.

Since there are no studies in the medical literature addressing the use of plastic fields to protect surgical instrument tables, examining whether there is a real need to use plastic fields during surgical procedures, stands out as subject worthy of study. Hence, we analyze the effectiveness of the routine use of plastic fields on surgical instrument tables in relation to the final outcome of SSIs, also considering the environmental impact of their disposal.

Therefore, this study's general objective was to analyze the use of sterile plastic fields and the use of $70 \%$ alcohol and $1 \%$ iodine on surgical instrument tables, used during clean surgeries, to impede the intraoperative contamination of the surgical site. The specific objectives were: to identify microorganisms and determine the number of colonies on surgical instrument tables; to determine bacterial resistance to antimicrobial agents used in hospitals; and to analyze the rate of SSIs among clean surgeries.

\section{Method}

This randomized experiment was conducted in the surgical center of a university tertiary hospital with 525 beds and an average of 1,524 surgical procedures from November 2010 to November 2011. Plastic fields, sterilized with ethylene oxide, are usually used on surgical instrument tables, placed under tissue fields, sterilized in an autoclave.

A statistician established the number of surgeries ( $n=70$ elective surgeries) required to achieve this study's objectives.

Two surgical instrument tables were set during clean procedures to collect microbiological material. Surgical instruments were placed on both tables organized as follows: 
- Surgical staff's table: used by the surgical staff during the procedure;

- Control table: remained exposed during, surgery but was not used by the surgical staff.

A random drawing determined the method of protection used for both surgical instrument tables (surgical staff's table and control table):

- Surgical instruments were placed on a table covered by a plastic field sterilized with ethylene oxide, itself placed under sterilized tissue field, or:

- Surgical instruments were placed on a table disinfected by $70 \%$ alcohol and $1 \%$ iodine and covered with a sterilized tissue field. In this method, one coating of solution was used, wiped on with a uniform rectilinear motion.

The authors themselves collected the material, together with two undergraduate assistant researchers, previously trained and accompanied by the researchers.

The patients participating in the study and their medical files were searched to check for surgical aspects and how their conditions progressed, both in the hospital and in ambulatory postoperative periods up to 30 days after the procedure.

The study project was submitted to and approved by the Institutional Review Board (Process No. 124/2010). The patients included in the study received clarification regarding the study's objectives and data collection was initiated only after they consented and signed free and informed consent forms. Patients younger than 18 years old were not included in the study.

Samples from the tables' surfaces were collected using aseptic techniques and sterile gloves at two different points in time: pre-surgery and post-surgery.

Five Rodac (Replicated Organisms Detection and Counting) plates containing Trypticase Soy Agar (TSA) were used to collect samples from the instrument tables through impression for $10 \mathrm{sec}$.

Representative colonies observed in the Rodac plates with TSA were identified concerning their morphology and staining characteristics after preparing the smears. Since only Gran-positive cocci were isolated, tests were used to characterize the microorganisms: oxidationfermentation, catalase and coagulase, through classical techniques(7). The sample Staphylococcus aureus ATCC 25923 was used as the control for the microbiological tests.

The susceptibility of cultures, characterized as the gender Staphylococcus, to antimicrobial classes was assessed "in vitro" using the gel diffusion test ${ }^{(8)}$. The following antimicrobial discs with registered trademarks were used: Cefoxitin (30 $\mu \mathrm{g})$, Clindamycin (2 $\mu \mathrm{g})$, Erythromycin $(15 \mu \mathrm{g})$, Gentamicin $(10 \mu \mathrm{g})$ and Rifampin $(5 \mu \mathrm{g})$. The D-test was performed to detect inducible clindamycin resistance.

Data were statistically analyzed using GraphPad Prism 5.0 for Windows. Univariate analysis, with contingency tables (Fisher's Exact test), was used. P-values $<0.05$ (level of significance at $5 \%$ ) were considered statistically significant.

\section{Results}

A total of 70 clean elective surgeries were monitored from November 2010 to November 2011. Plastic fields sterilized with ethylene oxide were used in 35 surgeries while disinfection with $70 \%$ alcohol and $1 \%$ iodine solutions were used on the remaining tables. A second surgical instrument table was assembled in all the surgeries but was not used by the medical staff.

The analysis concerning the number of positive tests for the surgical instrument tables in which plastic fields sterilized with ethylene oxide was used $(5.71 \%$ before and $28.6 \%$ after surgery) compared to disinfection with $70 \%$ alcohol and $1 \%$ iodine solutions (2.9\% before and $45.7 \%$ after surgery) showed no statistically significant differences (Table 1).

Table 1 - Number of positive tests for the tables used by the surgical staff and the control tables in relation to methods of protection, either $70 \%$ alcohol and $1 \%$ iodine or plastic fields previously sterilized with ethylene oxide, before and after surgery. Uberlândia, MG, Brazil, 2010-2011

\begin{tabular}{|c|c|c|c|c|c|c|}
\hline Table & Time of collection & $\mathrm{N}_{\mathrm{T}}{ }^{*} / \mathrm{N}^{\dagger}(\%)$ Plastic & $\mathrm{N}_{\mathrm{T}} / \mathrm{N}(\%)$ Alcohol $^{\ddagger}$ & $p^{\S}$ & OR\| & $\mathrm{Cl}_{95 \%}{ }^{\pi}$ \\
\hline \multirow[t]{2}{*}{ Surgical staff } & Before & $35 / 2(5.71)$ & $35 / 1(2.86)$ & 1.00 & 2.06 & $0.18-23.84$ \\
\hline & After & $35 / 10(28.57)$ & $35 / 16(45.71)$ & 0.21 & 0.47 & $0.18-1.28$ \\
\hline \multirow[t]{2}{*}{ Control } & Before & $35 / 3(8.57)$ & $35 / 1(2.86)$ & 0.61 & 3.19 & $0.31-32.26$ \\
\hline & After & $35 / 7(20.00)$ & $35 / 9(25.71)$ & 0.78 & 0.72 & $0.23-2.22$ \\
\hline
\end{tabular}

* Total number of tables; + Number of tables with positive tests; ₹ Alcohol 70\% and iodine 1\%; § Significance level; II Odds ratio; ๆ Confidence interval; 
The comparison between the number of colonies on the surgical instrument tables in relation to both protection procedures $(70 \%$ alcohol and $1 \%$ iodine versus plastic fields previously sterilized with ethylene oxide), before and after the surgery, did not show statistical differences $(p>0.05)$ (Table 2$)$.

Table 2 - Number of colonies on the surgical instrument tables according to protection procedures ( $70 \%$ alcohol and $1 \%$ iodine versus plastic fields previously sterilized with ethylene oxide) before and after surgery. Uberlândia, MG, Brazil, 2010-2011

\begin{tabular}{|c|c|c|c|c|c|}
\hline Time of collection & Table/Method & $\mathbf{N}^{*}\left(\mathbf{N}_{\mathbf{T}}\right)^{\dagger}$ & $\mathbf{p}$ & OR & $\mathrm{Cl}_{95 \%}$ \\
\hline \multirow[t]{4}{*}{ Before } & Surgical staff/Plastic & $2(98)$ & \multirow{2}{*}{0.57} & \multirow{2}{*}{1.07} & \multirow[b]{2}{*}{$0.09-12.07$} \\
\hline & Surgical staff /Alcohol & $1(52)$ & & & \\
\hline & Control/Plastic & $3(98)$ & \multirow{2}{*}{0.82} & \multirow{2}{*}{0.79} & \multirow{2}{*}{$0.13-4.91$} \\
\hline & Control/Alcohol & $2(52)$ & & & \\
\hline \multirow[t]{4}{*}{ After } & Surgical staff /Plastic & $41(98)$ & \multirow{2}{*}{0.06} & \multirow{2}{*}{0.51} & \multirow{2}{*}{$0.26-0.99$} \\
\hline & Surgical staff /Alcohol & $31(52)$ & & & \\
\hline & Control/Plastic & $57(98)$ & \multirow{2}{*}{0.37} & \multirow{2}{*}{1.41} & \multirow{2}{*}{$0.70-2.87$} \\
\hline & Control/Alcohol & $21(52)$ & & & \\
\hline
\end{tabular}

* Number of colonies; † Total number of colonies.

The presence of Gram-positive cocci, mainly Micrococcus, was found among the contaminant microorganisms, both on surfaces disinfected with $70 \%$ alcohol and $1 \%$ iodine $(81.8 \%)$ and those covered with plastic sterilized with ethylene oxide (94.9\%). Among the samples of Staphylococcus, $13.3 \%$ were characterized as Staphylococcus aureus (Table 3).

Table 3 - Species/genera of bacteria most frequently found among the analyzed surfaces. Uberlândia, MG, Brazil, 2010-2011

\begin{tabular}{lcc}
\hline \multicolumn{1}{c}{ Microorganism } & $\begin{array}{c}\text { Table }- \text { Sterile plastic } \\
\mathbf{N}^{*}=\mathbf{9 8}(\%)\end{array}$ & $\begin{array}{c}\text { Table }- \text { Alcohol } \\
\mathbf{N}=\mathbf{5 5}(\%)\end{array}$ \\
\hline Gram-positive cocci & $98(100.0)$ & $55(100.00)$ \\
Micrococcus spp & $93(94.9)$ & $45(81.8)$ \\
Staphylococcus sp & $5(5.10)$ & $10(18.2)$ \\
Staphylococcus aureus & $1(20.00)$ & $1(10.00)$ \\
Coagulase-negative staphylococcus & $4(80.00)$ & $9(90.00)$ \\
\hline
\end{tabular}

*Total number of Gram-positive cocci

The frequency of samples belonging to the phenotype Staphylococcus resistant to cefoxitin/oxacillin was $66.7 \%$, while one of the samples, characterized as Staphylococcus aureus (50.0\%), behaved as MethicillinResistant Staphylococcus Aureus (MRSA). This sample, however, did not behave like a multi-resistant strain, being susceptible to fluoroquinolones and aminoglycosides. Although, many of the samples of coagulase-negative staphylococci were resistant to the following: oxacillin, rifampin, clindamycin and erythromycin (Table 4).

Table 4 - Resistance profile of Staphylococcus samples. Uberlândia, MG, Brazil, 2010-2011

\begin{tabular}{lcccccc}
\hline \multirow{2}{*}{ Microorganism } & \multicolumn{3}{c}{ Resistance $\mathbf{N}^{*}(\%)$} \\
\cline { 2 - 6 } & $\mathbf{N}_{\mathbf{T}}{ }^{+}$ & Oxacillin & Gentamicin & Rifampin & Clindamycin & Erythromycin \\
\hline Staphylococcus aureus & 2 & $1(50.00)$ & $0(0.00)$ & $0(0.00)$ & $2(100.00)$ & $1(50.00)$ \\
Coagulase-negative staphylococcus & 13 & $9(69.23)$ & $0(0.00)$ & $3(23.08)$ & $4(30.77)$ & $6(46.15)$ \\
\hline
\end{tabular}

* Number of resistant microorganisms; + Total number of microorganisms

We also analyzed SSI risk factors that could interfere in our study. Using the classification provided by the American Society of Anesthesiology (ASA) in regard to associated comorbidities, we found that age, invasive procedures, duration of surgery, duration of antimicrobial use, and number of people in the surgery room, did not show statistical differences when the two methods were compared (Table 5). 
Table 5 - SSI risk factors. Uberlândia, MG, Brazil, 2010-2011

\begin{tabular}{|c|c|c|c|}
\hline Risk Factors & Plastic $N^{*}(\%)$ & Alcohol N (\%) & $\mathbf{P}^{\dagger}$ \\
\hline \multicolumn{4}{|l|}{ Associated comorbidities } \\
\hline Hypertension & $5(14.28)$ & $5(14.28)$ & 1.00 \\
\hline Age $>60$ years old & $9(25.72)$ & $3(8.57)$ & 0.11 \\
\hline Obesity & $1(2.86)$ & $0(0.00)$ & 1.00 \\
\hline$\geq 2$ comorbidities & $10(28.57)$ & $14(40.00)$ & 0.45 \\
\hline None & $10(28.57)$ & $13(37.15)$ & 0.61 \\
\hline \multicolumn{4}{|l|}{ ASA } \\
\hline ASA I & $16(45.71)$ & $16(45.71)$ & 1.00 \\
\hline ASA II & $19(54.29)$ & $19(54.29)$ & 1.00 \\
\hline \multicolumn{4}{|l|}{ Duration of surgery } \\
\hline$\leq 1$ hour & $14(40.00)$ & $11(31.43)$ & 0.62 \\
\hline$>1$ hour & $21(54.28)$ & $24(68.57)$ & 0.62 \\
\hline \multicolumn{4}{|c|}{ Number of people in the surgery room } \\
\hline$\leq 4$ & $18(51.43)$ & $15(42.86)$ & 0.63 \\
\hline$\geq 5$ & $17(48.57)$ & $20(57.14)$ & 0.63 \\
\hline \multicolumn{4}{|l|}{ Invasive procedures } \\
\hline Indwelling catheter & $1(2.86)$ & $3(8.57)$ & 0.61 \\
\hline None & $34(97.14)$ & $32(91.43)$ & 0.61 \\
\hline \multicolumn{4}{|l|}{ Duration of microbial use } \\
\hline$\leq 24$ hrs. & $17(48.58)$ & $13(37.14)$ & 0.47 \\
\hline$>24 \mathrm{hrs}$ & $9(25.71)$ & $17(48.58)$ & 0.08 \\
\hline Did not use & $9(25.71)$ & $5(14.28)$ & 0.37 \\
\hline \multicolumn{4}{|l|}{ Age } \\
\hline$\leq 60$ years old & $19(54.28)$ & $19(54.28)$ & 1.00 \\
\hline$>60$ years old & $16(45.72)$ & $16(45.72)$ & 1.00 \\
\hline
\end{tabular}

*Number of surgeries, + Level of significance

Finally, only one surgery $(2.68 \%)$, in which the plastic field sterilized with ethylene oxide was used, resulted in SSI, while no surgeries, in which disinfection with $70 \%$ alcohol and $1 \%$ iodine were used, resulted in SSI; no statistical difference was found.

\section{Discussion}

The analysis of surgical instrument tables that tested positive for microbiological presence, before and after surgery, with the use of both methods, showed no statistical differences. The presence of positive tests before the surgery, however, was not expected, especially on surfaces covered with sterilized plastic fields, since a company with a warranty certificate sterilizes this material. Hence, microorganisms were already present before surgery was initiated.

When we compared the total number of microorganisms on the surfaces of surgical instrument tables, with data reported in the literature, that is, acceptable levels of Colony Forming Units (CFU) for surgery rooms with conventional air systems (200 CFU/ $\mathrm{m}^{3}$ ) and for surgery rooms with ultra-clean air (50 CFU/ $\left.\mathrm{m}^{3}\right)^{(9-12)}$, we realized that acceptable levels of CFUs were found in both methods. Again, no statistical difference was found.

Studies show that the main organisms present in the air of surgical rooms include Micrococcus $s p$ and Staphylococcus $s p p$, reflecting their presence in human microbiota. The Staphylococcus aureus is frequently isolated, especially in surgeries with a lower level of contamination (clean). Currently, the coagulase-negative Staphylococcus is the second most frequent causative agent of SSIs ${ }^{(13-14)}$. Analysis of the microorganisms found on the surgical instrument tables, both those protected with plastic previously sterilized with ethylene oxide and those disinfected with $70 \%$ alcohol and $1 \%$ iodine, showed an absolute prevalence of Gram-Positive cocci, even though all types of microorganisms were surveyed. The Micrococcus genus predominated and there were cases of Staphylococcus aureus and coagulase-negative Staphylococcus, which is in agreement with the literature.

One study investigating contamination among nursing workers reports a higher incidence of Staphylococcus aureus among nursing technicians and auxiliaries. Nurses and nursing technicians, and much less frequently, nursing auxiliaries, also carried MRSA(15). 
About half of the Staphylococcus aureus samples and $75 \%$ of the Coagulase-negative Staphylococcus samples found in most American and Brazilian large hospitals are resistant to methicillin/oxacillin(16), which leads to an increasingly intense use of vancomycin(17). This information is corroborated in this study, since samples of the phenotype Staphylococcus resistant to cefoxitin/oxacillin were found both in Staphylococcus aureus and coagulase-negative Staphylococcus.

In relation to SSI risk factors, it is known that other factors besides those inherent to the innocuous bacteria, can contribute to the potential occurrence of SSI such as: ASA classification, patient age, invasive procedures, duration of surgery, associated patient comorbidities, duration of antimicrobial treatment, and number of people in the surgery room during surgery ${ }^{(3)}$. We assessed all these factors in this study and the statistical analysis showed no statistical differences, when both methods (plastic fields sterilized with ethylene oxide versus disinfection with $70 \%$ alcohol and $1 \%$ iodine) were compared, that indicated a higher or lower incidence of SSI in any of the methods.

Additionally, no statistical difference was found in regard to the occurrence of SSI in this study's patients, regardless of the method used. There was one case of SSI among the surgeries using sterilized plastic fields $(2.86 \%)$ and no cases of SSI among the surgeries using $70 \%$ alcohol and $1 \%$ iodine. A rate of $1.43 \%$ SSI was observed among all 70 of the clean surgeries monitored, which is within the rate $(2 \%)$ expected for clean surgeries ${ }^{(18)}$.

In addition to the factors previously discussed, the environmental impact caused by the disposal of plastic fields, which considerably increases the volume of hospital waste, should be taken into account. Incineration has been used to treat plastic waste, but it is not a recommendable method due to the high cost of warming ovens and the pollution it produces by releasing toxic products ${ }^{(19)}$.

\section{Conclusion}

Since no statistical differences were found between the use of plastic fields previously sterilized with ethylene oxide and disinfection with $70 \%$ alcohol and $1 \%$ iodine, both methods are considered efficient in the protection of surgical instrument tables during clean surgeries. Therefore, we encourage the use of $70 \%$ alcohol and $1 \%$ iodine to disinfect surgical instrument tables in all procedures performed in surgical facilities since this method is expected to cause a lesser environmental impact.

As limitations of this study, we mention the resistance of some professionals in relation to the collection of microbiological material, which limited the number of surgeries monitored and also prolonged the time spent in data collection.

The results of this investigation are relevant for the field of perioperative nursing because they support the choice and management of assembling and organizing a surgical room. The results also provide data concerning the contamination of surgical instrument tables, which can impact SSI indexes and directly affect patient safety and the risks to which patients are exposed due to the complexity of this hospital environment.

\section{References}

1. Nobre LF, Galvão CM, Graziano KU, Corniani F. Avaliação de indicadores do controle da contaminação da sala de operação: um estudo piloto. Medicina. 2001;34(2):183-93.

2. Lacerda RA. Fatores de risco relacionados ao ambiente e a limpeza da sala de operação. In: Lacerda RA, organizadora. Buscando compreender a infecção hospitalar no paciente cirúrgico. São Paulo: Atheneu 1992. $177 \mathrm{p}$.

3. Fernandes AT, Ribeiro N Filho, Oliveira AC. Infecções do Sítio Cirúrgico. In: Oliveira AC. Infecções Hospitalares Epidemiologia, Prevenção e Controle. Rio de Janeiro: Medsi; 2005. 732 p.

4. Martins MA. Manual de infecção hospitalar. Epidemiologia, prevenção e controle. 2. ed. Rio de Janeiro: Médica e Científica; 2001. 1152 p.

5. Knight R, Charbonnneau P, Ratzer E, Zeren F, Haun W Clark J. Prophylatic antibiotics are not indicated in clean general surgery cases. Am J Surgery. 2001;182:682-6.

6. Diogo A Filho, Mendonça CR, Jorge MT, Huang JH. Centro Cirúrgico: contaminação da mesa de instrumentais cirúrgicos. Avaliação de dois métodos de prevenção. In: Congresso Cirurgia 98 - Belo Horizonte; 30-02 maio 1998; Belo Horizonte, Minas Gerais. Belo Horizonte: Faculdade de Medicina da Universidade Federal de Minas Gerais; 1998.

7. Koneman EW, Allen SD, Janda WM, Schreckenberger PC, Winn WC. Diagnóstico microbiológico. 5 .ed. Rio de Janeiro: Guanabara Koogan; 2001. 1456 p.

8. Clinical and Laboratory Standards Institute. Performance Standards for Antimicrobial susceptibility Testing. 25th. ed. Pensylvania: Wayne; 2011. 
9. Graziano KU. Controle da contaminação ambiental da unidade de Centro Cirúrgico. Enfoque. 1994;1:19-22.

10. Portaria 3523, de 28 de agosto de 1998 (BR). Aprova Regulamento técnico contendo medidas básicas referente aos procedimentos de verificação visual do estado de limpeza, remoção de sujidade por métodos físicos e manutenção do estado de integridade e eficiência de todos os componentes dos sistemas de climatização, para garantir a qualidade do ar de interiores e prevenção de riscos à saúde dos ocupantes de ambientes climatizados. 1998 [acesso 1 jun 2012]. Disponível em: http://www.anvisa.gov.br/legis/ portarias/3523_98.htm

11. Pasquarella C, Pitzurra O, Savino A. The index of microbial air contamination. J Hosp Infect. [periódico na Internet]. 2000 [acesso 1 jun 2012]; 46:241-56. Disponível em: http://www.journalofhospitalinfection. com/article/S0195-6701\%2800\%2990820-X/abstract

12. Kelkar U, Bal AM, Kulkarni S. Fungal contamination of air conditioning units in operating theatres in India. J Hosp Infect. [periódico na Internet]. 2005 [acesso 23 mai 2012]; 60(1): 81-4. Disponível em: http://bscw.rediris. es/pub/bscw.cgi/d733667/MicrobialAirContamination

13. Associação Brasileira de Normas Técnicas. Tratamento de ar em Estabelecimentos Assistenciais de Saúde (EAS): requisitos para projetos e execução das Instalações. $2^{a}$ ed. Rio de Janeiro (RJ): Associação Brasileira de Normas Técnicas; 2005.

14. Boyce JM, Potter Boyne G, Chenevert C, King T. Environmental contamination due to methicillin-resistant Staphylococcus aureus: possible infection control implications. Infect Control Hosp Epidemiol. [periódico na Internet]. 1997 [acesso 1 jun 2012]; 18(9): 622-7. Disponível em: http://www.jstor.org/discover/10.2307/ 30141488 ? uid $=3737664$ \&uid $=2129$ \&uid $=2$ \&uid $=70$ \&ui $\mathrm{d}=4 \&$ sid $=21100847487171$

15. Moura JP, Pimenta FC, Hayashida M, Cruz EDA, Canini SRMS, Gir E. A colonização dos profissionais de enfermagem por Staphylococcus aureus. Rev. LatinoAm. Enfermagem. [periódico na Internet]. mar-abr 2011 [acesso 19 set 2012];19(2):[07 telas]. Disponível em: http://www.scielo.br/pdf/rlae/v19n2/pt_14.pdf

16. Lemmen $S$, Hafner $H$, Zolldann $D$, Stanzel $R$, Lutticken R. Distribution of multiresistant Gram-negative versus Gram-positive bacteria in the hospital inanimate environment. J Hosp Infection. [periódico na Internet]. 2004 [acesso 1 jun 2012]; 56(3):191-7. Disponível em: http://www.sciencedirect.com/science/article/pii/ S0195670103004717
17. Santos KR, Fonseca LS, Bravo NGP, Gontijo Filho PP. Surgical Site Infection: rates, etiology and resistance patterns to antimicrobials among strains isolated at Rio de Janeiro University Hospital. . J Hosp Infection. [periódico na Internet]. 1997 [acesso 23 mai 2012]; 25(4):217-20. Disponível em: http://www.journalofhospitalinfection. com/article/S0195-6701\%2803\%2900225-1/fulltext

18. Rui Z, Guangbei T, Jihong L. Study on biological contaminant control strategies under different ventilation models in hospital operating room. Building Environ. [periódico na Internet]. 2008. [acesso 23 mai 2012]; 43:793-803. Disponível em: http://www.sciencedirect. com/science/article/pii/S0360132307000236

19. Weinstain RA, Hayden MK. Multiplay drug-resistant pathogens: epidemiology and control. In: Bennett JV, Brachman PS, editors. Hospital infections. 4th. ed. Philadelphia: Lippincott-Raven; 1998. p. 215-36. 